\title{
THE CANNIBAL CAVALIER: SIR THOMAS LUNSFORD AND THE FASHIONING OF THE ROYALIST ARCHETYPE*
}

\author{
MARK STOYLE \\ University of Southampton
}

\begin{abstract}
A B ST RACT. This article re-examines the career of Sir Thomas Lunsford, one of the most notorious royalist officers of the English Civil War. Drawing on a wide range of contemporary sources, it not only casts new light on the pre-war activities of Lunsford himself but also explores the ways in which his blood-thirsty reputation was exploited by parliamentarian polemicists on the eve of the conflict. The article argues that, following the death of the proto-royalist playwright and plotter Sir John Suckling in I64I, Lunsford inherited Suckling's mantle as the archetypal 'cavalier', and that it was in association with Sir Thomas's name, rather than Sir John's, that the hostile caricature of the royalist gentleman-at-arms was first introduced to the English population as a whole. The article concludes by exploring the persistent rumours of cannibalism which have swirled around Lunsford's name for the past 370 years-and by demonstrating that, while the claim that Sir Thomas possessed a taste for human flesh may well have originated in the parliamentarian camp, it was, rather surprisingly, royalist writers who subsequently did most to keep his anthropophagical reputation alive.
\end{abstract}

'Cavaliers and roundheads': the popular party-labels which were applied to the supporters of Charles I and parliament during the Great Civil War of 1642-6 have continued to haunt the English historical imagination ever since. It seems fair to suggest that-of the two stereotypical figures which those nicknames instantly summon up in the mind's eye-that of the cavalier is, by some way, the most vivid and powerful. Over the past $35^{\circ}$ years, the figure of the cavalier has proved a rich source of inspiration for creative souls of all

History Department, The University, Southampton, SOI7 IBF mjs@soton.ac.uk

* This article is a revised version of my inaugural lecture, which was delivered at the University of Southampton in 2014. I am grateful to everyone who attended on that occasion and who spoke to me about the cavalier archetype afterwards, most of all to John Walter. I am indebted to the editor of the Historical Journal and to the two anonymous readers for their comments on an earlier draft of this article - and to George Bernard, who also read the text. Finally, I would like to thank all of the former students who have discussed Sir Thomas Lunsford with me over the years, especially Chris Lawrence, Henry Gill, and Steph Kirkham. 
sorts, including dramatists, novelists, journalists, painters, and poets. ${ }^{1}$ As a result, that figure enjoys remarkable brand-recognition, brand-recognition which both popular and academic historians of the Civil War have simultaneously capitalized upon and helped to reinforce: by insinuating the word 'cavalier(s)' into the titles of their books, for example, by choosing Victorian paintings of imagined cavaliers to adorn their dust-jackets, and by employing the term 'cavalier' as a synonym for 'royalist' in their texts. ${ }^{2}$ Yet despite - or even, perhaps, because of - the word's continued ubiquity, the origins of this most familiar of English historical soubriquets remain surprisingly obscure. In recent years, the work of Alexandra Walsham, Ethan Shagan, Phil Withington, and others has taught us to pay far more careful attention to the precise meanings with which specific words were freighted during the early modern period - and to how those meanings could sometimes alter over time as familiar terms became, in Withington's words, 'politicised, appropriated and popularised in new and unexpected ways'. ${ }^{3}$ The party label 'cavalier' - a label which, as Blair Worden has well observed, was a product of that pre-war process of ideological mobilization by which 'the opposing sides learned to caricature one another' - is clearly worthy of consideration through a similarly close-up lens. 4 For while there are scores of more or less detailed definitions of what the partisan term 'cavalier' was held to denote after 1642 , there are far fewer discussions of precisely when that term first appeared on the public stage - and of how the anonymous individuals who coined it had thereby

${ }^{1}$ See, for example, A. Benn, The rover, or the banish't cavaliers (London, 1677); W. Scott, Woodstock, or the cavalier (3 vols., Edinburgh, 1826); E. Warburton, ed., Memoirs of Prince Rupert and the cavaliers (3 vols., London, 1849); W.S. Burton, 'The wounded cavalier' (painted in 1855, exhibited in 1856); and R. Browning, Cavalier tunes: the lost leader and other poems (Boston, MA, 19o6).

${ }^{2}$ For cavalier book-titles, see, for example, M. Bence-Jones, The cavaliers (London, 1976); and C. Spencer, Prince Rupert: the last cavalier (London, 2007). For book-covers featuring paintings of imagined cavaliers by Charles Landseer, and John Pettie respectively, see P. Tennant, Edgehill and beyond: the people's war in the South Midlands, I642-I645 (Stroud, 1992); and M. Bennett, The Civil Wars in Britain and Ireland, I638-I65I (Oxford, 1997). For the use of 'cavalier' as a synonym for 'royalist' by modern academic historians, see, for example, D. Underdown, Revel, riot and rebellion: popular politics and culture in England, I603-I660 (Oxford, 1985), p. 167 .

3 See A. Walsham, Charitable hatred: tolerance and intolerance in England, I50o-I70o (Manchester, 2006); E. H. Shagan, The rule of moderation: violence, religion and the politics of restraint in early modern England (Cambridge, 2011); and P. Withington, 'The semantics of "peace" in early modern England', Transactions of the Royal Historical Society (TRHS), 6th ser., 23 (2013), pp. 127-53, at p. 127.

4 B. Worden, Roundhead reputations: the English Civil Wars and the passions of posterity (London, 2001), p. 2. For the concept of rival ideological 'mobilizations' during the months before the conflict began, see M. J. Braddick, 'Prayer book and Protestation: anti-popery, anti-puritanism and the outbreak of the English Civil War', in C. W. A. Prior and G. Burgess, eds., England's wars of religion revisited (Aldershot, 2011 ), pp. 125-45, passim, especially pp. 135-6; and idem, 'History, liberty, reformation and the cause: parliamentarian military and ideological escalation in 1643', in M.J. Braddick and D. L. Smith, eds., The experience of revolution in Stuart Britain and Ireland (Cambridge, 2011 ), pp. 117-34, especially p. 132. 
succeeded in fashioning an overarching royalist stereotype even before the conflict had begun.5 The best work on this neglected subject has been carried out by the literary scholars T. N. Corns, Timothy Raylor, and Robert Wilcher, all of whom have argued that the hostile caricature of the cavalier initially began to coalesce around the person of the pre-war poet and dramatist Sir John Suckling. ${ }^{6}$ The present article suggests that, while this thesis is undoubtedly correct, it tells only part of the story, and that the second key figure in the protoparliamentarian invention of the cavalier was the Sussex gentleman Colonel Thomas Lunsford.7

The article is divided into six parts. The first considers what previous historians have had to say about Lunsford. The second reviews the events of Lunsford's turbulent youth, and his service as a regimental commander in the army which Charles I sent to fight the Scots in 1640. The third part shows how, following Charles's humiliating defeat and the consequent collapse of the royal regime, Lunsford returned to London, where the key ingredients of what would later become the royalist archetype were already beginning to form. The fourth part shows how Lunsford suddenly shot to national prominence in 1641 , when he was appointed as lieutenant of the Tower by Charles, and how he was then subjected to a campaign of vilification by the king's critics in parliament, as they sought to discredit the new lieutenant and, through him, his royal master. Here, it will be argued that, with Suckling now dead, Lunsford - who was presented in the most lurid light in the proto-parliamentarian pamphlets which were then beginning to proliferate in the capital-effectively inherited Sir John's mantle. As a result, he became the first notorious 'cavalier', and, in the process, played a significant, if wholly involuntary, role in the fashioning of that hostile caricature of the royalist gentleman-at-arms

${ }^{5}$ For a detailed discussion of some of the ways in which the word 'cavalier' was used during the Civil War itself, see I. Roy, 'Royalist reputations: the cavalier ideal and the reality', in J. McElligott and D.L. Smith, eds., Royalists and royalism during the English Civil Wars (Cambridge, 2007), pp. 89-111.

${ }^{6}$ See T. N. Corns, J. A. Downie, and W. A. Speck, 'Archetypal mystification: polemic and reality in English political literature', Eighteenth Century Life, 7 (1982), pp. 1-27, at p. 4; T. N. Corns, ed., The Cambridge companion to English poetry: Donne to Marvell (1993; Cambridge, 2001 edn), pp. 201-2; T. Raylor, Cavaliers, clubs and literary culture: Sir John Mennes, James Smith and the Order of the Fancy (Newark, DE, 1994), p. 109; and R. Wilcher, The discontented cavalier: the work of Sir John Suckling in its social, religious, political and literary contexts (Newark, DE, 2007), pp. 332-6.

7 For previous accounts of Lunsford, see G. Steinman-Steinman's pioneering 'Memoir of Sir Thomas Lunsford, baronet' (parts 1-4), Gentleman's Magazine (GM) (Apr. 1836), pp. 35o-7; $G M$ (June $188_{36}$ ), pp. $602-4$; $G M$ (July 1836 ), pp. $3{ }^{2-5}$; $G M$ (Aug. 1836 ), pp. $14^{8-54}$; W. H. Blaauw, 'Passages of the Civil War in Sussex from 1642 to 1660', Sussex Archaeological Collections (SAS), 5 (1852), pp. 80-3; 'W.A.S.', 'Lunsford, Sir Thomas, 1610 ?-1653?', in S. Lee, ed., Dictionary of national biography (London, 1893), pp. 281-3; C. Thomas-Stanford, Sussex in the Great Civil War and Interregnum, I642-I660 (London, 1910), pp. 19-21; P. R. Newman, Royalist officers in England and Wales, I642-1660: a biographical dictionary (London, 1981 ), p. 242; and B. Morgan, 'Lunsford, Sir Thomas, b. circa 1610 , $d$. in or before 1656 ', in Oxford dictionary of national biography (ODNB) (Oxford, 2004), pp. 775-7. 
which would shortly go on to establish itself as one of the most enduring party stereotypes in English history. ${ }^{8}$ Having demonstrated how Lunsford was pressed into service as a proto-royalist bugbear during $1641-2$, the article then goes on explore how his fearsome reputation continued to be elaborated upon as England fell into civil war during $164^{2-3}$. Finally, it investigates the tangled origins of the most famous of all the contemporary rumours that circulated about Lunsford: the rumour that he possessed a penchant for eating human flesh.

\section{I}

'A debauched ruffian', a 'bold and violent swaggerer', and 'a blustering rakehell': these are the epithets which were chosen by S. R. Gardiner, C.V. Wedgwood, and J. P. Kenyon respectively to describe Sir Thomas Lunsford.9 Nor should it be thought that these writers were in any way atypical in their attitude towards Lunsford, for-although he was one of the minor celebrities of the Civil War, and makes at least a fleeting appearance in most general histories of the conflict - few historians have found anything very complimentary to say about him. On the contrary, Lunsford has been almost universally condemned by scholars, who have variously characterized him as 'brutal'; ${ }^{10}$ 'notorious'; ${ }^{11}$ 'unscrupulous'; '12 'thuggish';13 and straightforwardly 'murderous'. ${ }^{14}$ The present article does not seek to turn this hostile view of Lunsford on its head; to suggest, with Peter Newman - one of Sir Thomas's few scholarly defenders that he was the blameless victim of 'innuendo and hearsay'.15 Rather, what it sets out to do is to provide a slightly more nuanced view of Lunsford than the one which appears in the standard histories - a view which occasionally comes perilously close to being a simple restatement of what was said about Sir Thomas by his enemies at the time. ${ }^{16}$ That this should be so, of course, reflects the abiding power of the negative image of him which was constructed

${ }^{8}$ For a previous one-line suggestion that the image of the cavalier might have been partly modelled on Lunsford, see D. Hirst, England in conflict, I6o3-166o: kingdom, community, commonwealth (London, 1999), p. 193, and, for a recent description of Lunsford as 'an archetypal cavalier', see D. Cressy, England on edge: crisis and revolution, I640-I642 (Oxford, 2006), p. 108.

9 S. R. Gardiner, History of England from the accession of James I to the outbreak of the Civil War $(10$ vols., London, 1884), x, p. 108; C. V. Wedgwood, The king's war, I64I-I647 (1958; London, 1983 edn), p. 49; and J. P. Kenyon, The Civil Wars of England (London, 1988), p. 26.

${ }^{10}$ A. Woolrych, Britain in revolution, I625-166o (Oxford, 2002), p. 208.

11 A. Hughes, The causes of the English Civil War (London, 1991), p. 174.

12 R. Cust, Charles I: a political life (Harlow, 2005), p. 317.

13 J. Miller, The English Civil Wars: roundheads, cavaliers and the execution of the king (London, 2009), p. 8o.

14 N. Carlin, The causes of the English Civil War (Oxford, 1999), p. 33.

${ }_{15}$ See P. R. Newman, The old service: royalist regimental colonels and the Civil War, I642-I646 (Manchester, 1993), pp. 109, 143-5, 301 (quotation at p. 145).

${ }_{16}$ As Newman rightly observes, see Old service, p. 145. 
during the 1640s: a subject which we will return to later. But first we must consider the man behind the myth.

\section{I}

Thomas Lunsford, the eldest son of Thomas Lunsford of East Hoathly in Sussex and his wife, Katherine, was probably born at Bearstead in Kent in 1604. ${ }^{17}$ The Lunsfords were an ancient gentry family, who could trace their roots in Sussex back to the time of the Conquest, but by the time that Charles I acceded to the throne their financial position was deteriorating - and, to make matters worse, they had fallen out with a wealthy neighbour, Sir Thomas Pelham. ${ }^{18}$ Thomas Lunsford grew up to be a strapping young fellow-according to a later writer, indeed, he was one of 'the biggest men...you could likely see' - and several pieces of evidence suggest that he soon developed a propensity for brawling and violence. ${ }^{19}$ By the early 1630 , Thomas had become an active participant in his family's continuing feud with Pelham. ${ }^{20}$ The latter subsequently complained that Thomas had not only poached deer from his park, but that he had violently assaulted his park-keepers and had publicly declared that 'he cared not a fart' for Pelham himself. ${ }^{21}$ In 1633, Lunsford, infuriated by the legal proceedings which Pelham had initiated against him, determined to exact a wild revenge. It was subsequently claimed that Thomas lay in wait for Pelham one Sunday as he was leaving church and fired two or three shots into his coach as it passed by. ${ }^{22}$ This could clearly have been construed as an act of attempted murder - as, indeed, it probably was-and, soon afterwards, Lunsford was committed to prison in London by order of the privy council,

${ }^{17}$ Lunsford is usually said to have been born in 'circa 1610'; see, for example, Morgan, 'Lunsford', p. 775. For what appears to be the true, rather earlier, date of his birth, see Kent Archives Office, Kent History and Library Centre, Maidstone, DCa/BT/11.1 (Archbishop's Transcripts for Bearstead), fo. 6. I owe my knowledge of this document to my former student, Steph Kirkham. For further information about Lunsford's parentage and ancestry, see British Library (BL), Harley MS, 892, fo. $16 \mathrm{v}$.

${ }^{18}$ On the Lunsfords' feud with Pelham, see Steinman-Steinman, 'Memoir', part 4, pp. ${ }_{1} 5^{1-}$ 2; idem, 'Letters relating to the Lunsford family', GM (Mar. 1837), pp. 265-6; and M. Lower, 'Observations on the buckle: the badge of the family of Pelham', SAS, 3 (185o), pp. 223-4. On Pelham himself, see A. Fletcher, A county community in peace and war: Sussex, I60o-I66o (London, 1975), pp. 13, 27-9, 32-4, 43, 49, 54-5, 241, 243, 248, 252.

${ }^{19}$ For Lunsford's physical bulk, see D. Lloyd, Memoires of the lives... of those...that suffered... for the Protestant religion (London, 1668), p. 581 . For his attempts to provoke a duel with another young man in London, see R. Cust and A. Hopper, eds., Cases in the High Court of Chivalry, I634-I640 (Harleian Society, New Series, 18, 2006), pp. 308-9; and R. Cust, Charles I and the aristocracy, I625-1642 (Cambridge, 2013), p. 147.

${ }^{20} \mathrm{~J}$. Rushworth, Historical collections of private passages of state (8 vols., London, $\left.1721-2\right)$, III, Appendix (Star Chamber reports, Michaelmas 8 Charles I), pp. 47-8.

${ }_{21}$ Ibid., III, pp. 47-8; and T. Birch, ed., The court and times of Charles the first (2 vols., London, 1849), II, p. 182.

${ }_{22}$ Rushworth, Historical collections, Iv, p. 46o; and The National Archives, Kew (TNA), SP 16 / 369 , fo. 163 . 
for what his gaoler later described as 'a foul attempt upon Sir Thomas Pelham'.23

In October 1633, Edward Sackville, fourth earl of Dorset, wrote to Pelham assuring him that he and the rest of the council were poised to act against 'thatt yong outtlaw, Mr Lunsfurd, who nether feares God nor man, and who, havinge given himselfe over unto all leudness and dissoluteness, only studyes to affront justice...[taking] a glory to bee esteemed...a swaggeering ruffian'. ${ }^{24}$ This lively description of Thomas has been reproduced by legions of historians and may well be a fair summing-up of his character, but, in justice to Lunsford, it must be stressed that Dorset - who was clearly friendly with Pelham - should not be regarded as an entirely unbiased witness. Over the following months, Lunsford continued to languish in Newgate prison, but in 1634 -after his gaoler had rashly permitted him to exchange his prison cell for more comfortable lodgings in town-Lunsford broke his parole and made his way to the continent. ${ }^{25}$ Here, he embarked on a career as a soldier of fortune, and in ${ }_{16} 6_{3} 6$ it was reported from Paris that Lunsford was in Picardy where he was planning to raise a regiment of soldiers to fight for the king of France. ${ }^{26}$

A year later, the case against Lunsford was finally heard in Star Chamber. He was fined $£ 8$, ooo for his attempt on Pelham, and outlawed for his own failure to appear-and at this point it must have seemed probable that Thomas would either remain in exile for ever or die in the French king's service. ${ }^{27}$ Yet the Scottish rebellion of 1637-8 transformed Lunsford's fortunes. In 1639, Charles began to raise an army to bring the Scots to heel. It was obvious that he would need experienced officers, and at some point somebody seems to have suggested that Thomas-who was by now serving as a colonel in the French king's service-might well prove a useful commander, despite his rackety past. Certainly, Lunsford returned to England in 1639 and received a royal pardon for his crimes. ${ }^{28}$ Then, in early 1640 , he was commissioned as colonel of an infantry regiment, which he was to raise in Somerset and lead

23 For a letter of 15 Aug. 1633 from Attorney General Noy, asking to see 'the examinations concerning Mr Lunsford', which almost certainly refers to the case of Thomas Lunsford junior, see Calendar of state papers, domestic (CSPD), I633-I634, p. $18_{3}$. For the gaoler's subsequent comment, see CSPD, I634-I635, p. 308 .

${ }^{24}$ Sackville to Pelham, 28 Oct. 1633 , Hampton Court, BL, Additional MS, 5682, fo. 278.

${ }^{25}$ CSPD, I634-I635, pp. 257, 308, 471 .

26 CSPD, $1635^{-1} 636$, p. 322.

27 'W.A.S.', 'Lunsford', p. 282 ; and TNA, SP $16 / 369$, fos. $160-4$.

${ }^{28}$ For Lunsford's undated petition asking Charles to pardon him and to remit the two fines which were owed by him to the crown, see Steinman-Steinman, 'Memoir', part 4, pp. $15^{2-3}$. Note also Sir John Coke's endorsement of the petition, confirming that Charles 'is graciously pleased to pardon his offences, and to remit ye fine', dated 'at the Court at York, 24 April 1639'. See also Historical manuscripts commission (HMC), De Lisle and Dudley, vi (1966), p. 192; and CSPD, I 640 , p. 542 . 
north to fight the Scots. ${ }^{29}$ This was a signal mark of royal favour, of course, but, like so many of the gentlemen who had been commissioned to serve as officers in the new army, Lunsford swiftly found that he had been handed a poisoned chalice. The English people had little appetite for the fight and hundreds of the soldiers who had been pressed for the service proved openly mutinous. This was certainly true of Lunsford's recruits and no sooner had Thomas set out for the north than he found that he was in grave danger of being killed by his own men. On 22 June, Lunsford sent a gloomy letter to the general of the English army from Warwick, where he had made a halt on his march. 'My Lord', wrote Lunsford:

I find my regiment in [the] greatest disorder; divers of them in troopes retourned home, [and] all in a forwardnes to disbande...We [that is to say, Lunsford and his

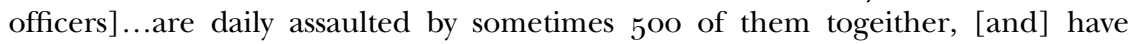
hurt and killed some in our owne defence... Notwithstanding, we march still forward with as many as we can but...I assure your Excellency, the officers...lives have bin in danger every houre since theire march..$^{\circ}$

It is worth observing here, perhaps, that this letter is perfectly well phrased and literate; whatever else Lunsford may have been, he was clearly not the uneducated brute of legend..$^{1}$ And while he certainly reported that he and his officers had been forced to kill several of their mutinous soldiers in our owne defence', this is not quite the same thing as 'boast[ing]' that he had 'shot a couple of mutineers out of hand', as his biography in the most recent edition of the Dictionary of national biography claims that he did. ${ }^{2}$

Lunsford was clearly fearful of being killed himself, and he was by no means alone in this, for across the whole of England, the king's disaffected soldiers were by now mutinying, rioting, and attacking their officers - several of whom were savagely beaten to death.33 The Scots were well aware of the chaos in

29 For a letter from the lord lieutenant of Somerset to the general of the English army, dated 22 May, stating that 'Colonel Lundesfords' officers were already raising soldiers in Somerset, see CSPD, I64o, p. 203.

$3^{\circ}$ Lunsford to the earl of Northumberland, 22 June 1640 , Warwick, TNA, SP 16/457, fo. 91. For the privy councillors' discussion of the mutiny among Lunsford's troops six days later, see Rushworth, Historical collections, III, p. 1191 . For the royal proclamation 'for [the] apprehending and punishing of [mutinous] souldiers' which was issued in the wake of this discussion, on 1 July, see J. F. Larkin, ed., Stuart royal proclamations, II: Royal proclamations of King Charles I, I625-I646 (Oxford, 1983), pp. 716-18. For the subsequent misbehaviour of Lunsford's men near Derby, see HMC, Twelfth report, appendix, part II, the manuscripts of the earl of Cowper (1884), pp. $257-8$.

$3^{1}$ For Edward Hyde's comment that Lunsford was 'of no good education', see E. Hyde, earl of Clarendon, The history of the rebellion and Civil Wars in England, ed. W. Dunn Macray (6 vols., Oxford, 1888), I, p. 478 .

$3^{2}$ Morgan, 'Lunsford', p. 776.

33 On the soldiers' mutinies of 1640 , see M. C. Fissel, The bishops' wars: Charles I's campaigns against Scotland, I638-I64o (Cambridge, 1994), ch. 7, pp. 264-86; M. Stoyle, Loyalty and locality: popular allegiance in Devon during the English Civil War (Exeter, 1994), pp. 168-9; and Cressy, England on edge, pp. 68-1og. 
their enemies' ranks, and on 20 August, they invaded England.34 Eight days later, they attacked the English forces which had gathered to block their way at Newburn.35 Lunsford was on the front line and during the engagement which followed he displayed real courage. $3^{6}$ His example was not enough to infuse the king's army with the fighting spirit it so patently lacked, though, and it was not long before the English forces retired from the fray, leaving the exultant Scots in possession of the field. Newburn was one of the most humiliating defeats in English military history. But Lunsford emerged from the debacle with his reputation intact-and indeed Conrad Russell has gone so far as to suggest that the battle was the making of him, observing that those 'who fought bravely at Newburn, including...Lunsford, retained for ever after a special hold on Charles's affections'.37 The evidence on which Russell based this claim is not entirely clear, as far as Lunsford is concerned, but the suggestion that Thomas's conspicuous display of valour at Newburn may have confirmed the king's trust in him does seem perfectly plausible.

Certainly, Newburn marked the end of the line for the personal rule. Worsted by the Scots, Charles was forced to patch up a hasty treaty with them, by the terms of which he agreed to pay the Scottish army - as well as his own army, in Yorkshire-until a permanent peace settlement had been concluded. Without the help of parliament, there was simply no way that he could do this and, accordingly, writs went out for the momentous assembly which would later become known as the Long Parliament. Once the new MPs had begun to sit, in November 1640 , they quickly seized the initiative. Rather than helping the king against the Scots they set to work to reform the state, to dismantle the structures on which the personal rule had been based. A new political world was rapidly evolving and, as we shall see, it was a world in which army officers like Lunsford were soon to find themselves increasingly embroiled.

\section{I I}

During the early months of 1641 , the pace of political 'reformation' in London quickened, as many of the king's ministers were arrested, and his prerogative courts were voted down. Charles I's critics seemed to be in complete control. Yet, already, knots of ultra-loyalists were scheming to turn the tide, and among them were a number of army officers: some of whom had by now made their way to the king's side in the capital, others of whom were still at the head of their units in the north. $3^{8}$ In March, a small coterie of these men

34 Cust, Charles I, p. 263.

35 Fissel, Bishops' wars, pp. 54-6.

$3^{6}$ Rushworth, Historical collections, III, pp. $123^{6-7}$.

37 C. Russell, The fall of the British monarchies, I637-I642 (Oxford, 1992), p. 145 .

$3^{8}$ For these machinations, see C. Russell, 'The first army plot of 1641 ', TRHS, 5 th ser., $3^{8}$ (1988), pp. $85^{-106 .}$ 
began to discuss the possibility of bringing the English army down to London in order to overawe the parliament, while plans were made to seize the Tower.39 Prominent among the conspirators was the courtier-poet, Sir John Suckling, who had served, like Lunsford, in the army raised during the previous year. $4^{\circ}$ On 2 May, Suckling gathered a party of armed men and attempts were made to have these irregular soldiers admitted to the Tower in the king's name. ${ }^{4^{1}}$ Yet the plan failed, and, as news of what appeared to have been an abortive military coup spread, protests erupted on the city's streets. $4^{2}$ Soon afterwards, Suckling and several of the other officers who had been involved in what their enemies now termed 'the Army Plot' fled abroad, where Sir John subsequently died. 43

The flight of Suckling and his co-conspirators is a key episode for our purposes, because it was in the wake of their hurried departure that a hostile writer first seems to have referred to the most militant supporters of the king as 'cavaliers'. Before we examine precisely how that crucial conjunction occurred, though, we should pause for a moment to consider the etymology of the word 'cavalier' - which was not newly minted in 1641 , as general histories of the Civil War so often imply, but had instead been familiar in English for many years before.44 Originally derived from the Latin word caballarius, meaning 'a horseman', the term had later become transmuted into the Spanish caballero and the French chevalier, and had then been imported from those languages into English, where it was already well-established by Shakespeare's day.45 It is important to stress, however, that, in sixteenthcentury English, the word had two variant forms, which possessed distinct, if often overlapping, meanings.

On the one hand, there was 'the cavalier', or 'courageous military man': the sort of person whom Shakespeare clearly had in mind when he caused the Chorus in Henry $V$ to refer, admiringly, to those 'culled and choice-drawn cavaliers' who were preparing themselves for battle on the vasty fields of France. On the other hand, there was 'the cavaleiro', or 'gallant man of fashion': the sort of person whom Shakespeare equally clearly had in mind when he caused Justice Shallow to swear that he would drink a health to 'all the cavaleros about London' in Henry IV, part 2. $4^{6}$ As Shallow's speech suggests, the word 'cavaleiro'

39 Russell, 'Army plot', passim.

$4^{\circ}$ On Suckling, see T. Clayton, 'Suckling, Sir John (16o9-1641)', in ODNB, pp. 264-70; and Wilcher, Suckling, passim.

$4^{1}$ For Suckling's botched attempted to seize the Tower, see Russell, 'Army plot', pp. 95-6; and J. Adamson, The noble revolt: the overthrow of Charles I (London, 2007), pp. 279-84.

$4^{2}$ See Adamson, Noble revolt, pp. 284-9o; and B. Manning, The English people and the English revolution (London, 1991), p. 61.

43 Russell, 'Army plot', passim; and, for Suckling's death, Wilcher, Suckling, pp. 328-30.

44 A point which is well made in Cressy, England on edge, p. 107.

45 The Oxford English dictionary.

${ }^{4} 6$ W. Shakespeare, King Henry $V$, Act III, prologue; and idem, The second part of Henry IV, Act v, Scene iii. 
tended to be especially associated with drink and sexual licence and in 1612 we find the 'water-poet', John Taylor, painting a splendid portrait of a young London gallant-or 'Cavalero Hot-shott', as Taylor vividly terms him-being rowed across the Thames in a wherry, yelling all the while at the sweating oarsmen 'Zoun[d]s! Rowe, ye Rog[ue]s! Ye lazy knaves, make hast; a noyse of Fidlers and a brace of whores [await me] at Lambeth!'47

While Shakespeare appears to have drawn a distinction between the cavalier and the cavaliero, the two figures soon became increasingly blurred -and this was certainly the case in an anonymous graphic satire which was published in London at some point after Suckling's flight to France in May 1641: a satire whose iconography - as Helen Pierce has rightly noted - was later to inform 'a host of cavalier images'. $4^{8}$ Entitled The Sucklington Faction: Or (Suckling's) Roaring Boyes, this engraved broadsheet depicts two fashionable young gentlemen sitting together in a low room, with drink, dice, and playing-cards by their sides (Figure 1). It is almost superfluous to point out that, as Pierce implies, in their costume and general demeanour these two individuals may be said to epitomize the way in which most people still imagine 'the cavalier' to this day. What Pierce does not comment upon, though-and what is crucial for our purposes - is that in the highly condemnatory text which accompanies the engraving, the two gallants are specifically described as 'hot-spur Cavaliers'. 49 Here, then, we find the word 'cavaliers' - which was already suggestive both of military men and drunken roisterers - being specifically associated with the most hard-line supporters of the king.

It was during the literary offensive which was mounted by proto-parliamentarian polemicists against Sir John Suckling in mid-1641 that the word 'cavalier' first seems to have been appropriated and subtly re-modelled in order to serve as a partisan term of abuse, in other words. Nor can there be much doubt that it was from Suckling's own literary oeuvre that the soubriquet which would later go on to become so famous had initially been derived, for, in the letters, poems, and plays which he had written during the 1630 os, Sir John had made frequent use of the term 'cavalier' to describe both gallants and soldiers, while in his stage-play, Brennoralt, written in the aftermath of the First Bishops' War, Suckling had included three characters whom he specifically termed 'Cavaliers', and who were surely intended to represent officers who had

$47 \mathrm{~J}$. Taylor, The sculler, rowing from Tiber to Thames (London, 1612), epigram 13 .

$4^{8}$ BL, E.669, f.4 (1 7), The Sucklington Faction: Or (Sucklings) Roaring Boyes (single-sided broadsheet, n.p., 1641); and H. Pierce, Unseemly pictures: graphic satire and politics in early modern England (London, 2008), p. 144. John Adamson suggests that this broadsheet was first published in Dec. 1641 - or even in 1642 - but provides no evidence to support this contention, see Noble revolt, plate between pp. 394 and 395, caption; and p. 698 n. 54. It is surely more probable that the broadsheet made its appearance during the period in which public interest in Suckling was at its height; that is to say, during the weeks immediately following Sir John's attempt to introduce soldiers to the Tower in May 1641 and his subsequent flight.

49 BL, E.669, f.4 (17). 


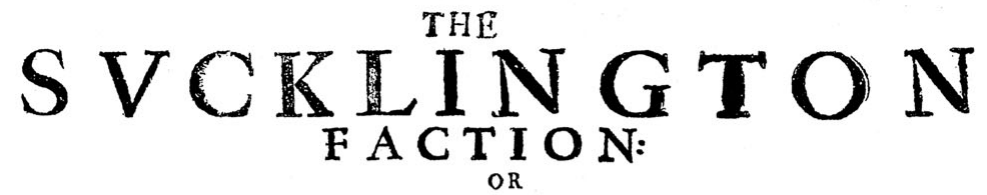
(SUCKLIN(GS) Roaring Boyes.)

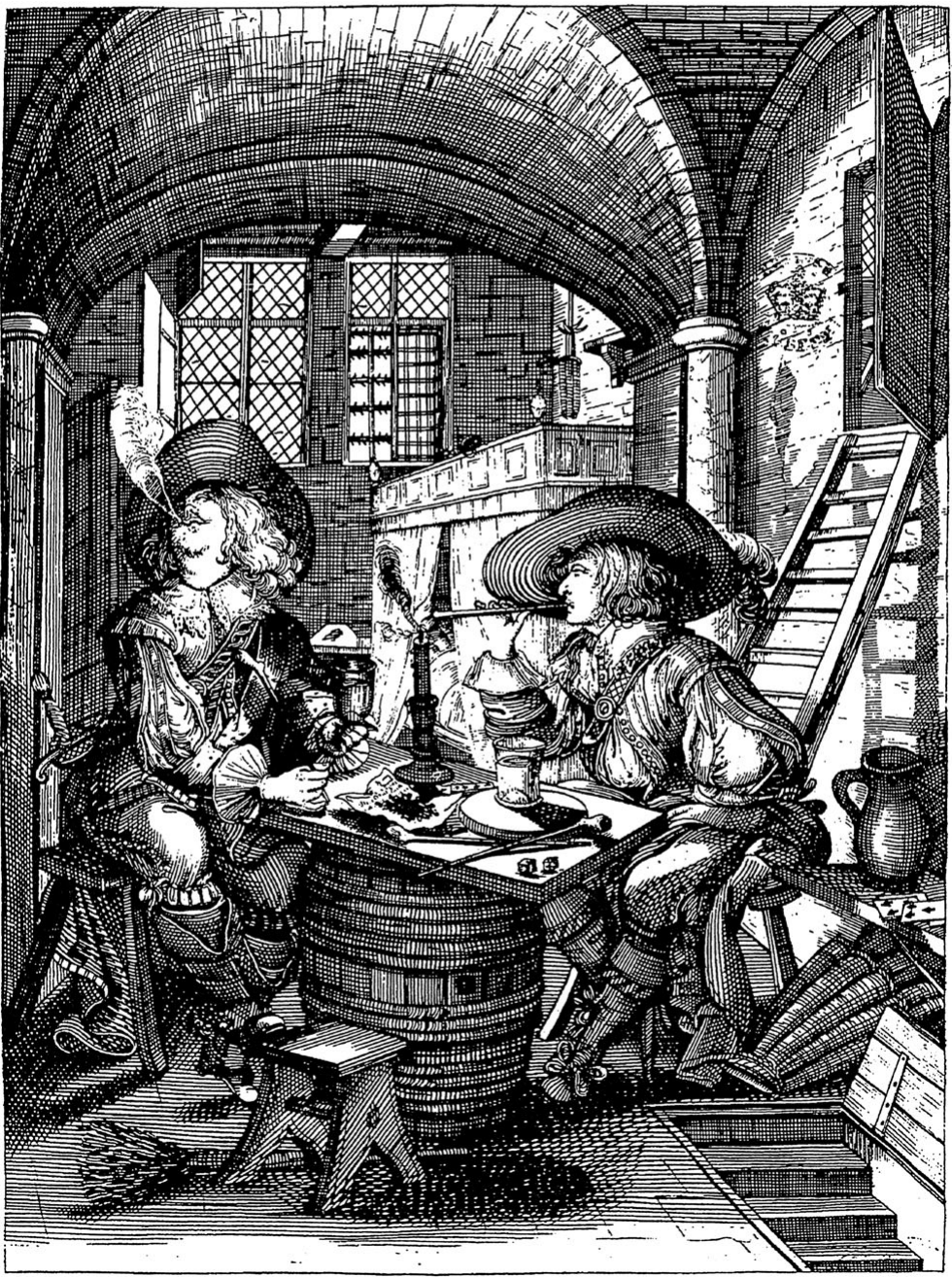

Fig. 1. The Sucklington Faction: Or (Sucklings) Roaring Boyes, [June?] 1641. (C British Library Board, E.669, f.4 (17). 
served the king in the recent campaign against the Scots. $5^{\circ}$ By describing Sucklington and his confrères as 'cavaliers', therefore, the anonymous satirist of $164^{1}$ was not only cracking a literary in-joke-one which parodied Sir John's faux-chivalrous writing style-but was also subtly underscoring the point that it was among ex-army officers that the most determined resistance to parliament's proceedings was to be found..$^{1}$

Whether the satirist was the first person to apply this particular word to the king's most fervent supporters must remain a moot point, however, for it is fascinating to note that, in a verse epistle which was penned in May or June 1641 , but not published until many years later, the Devon parson James Smith - then resident in London - likewise referred to the army plotters as 'Chevaliers' $5^{2}$ Smith belonged to a proto-royalist literary circle which possessed many connections with those who had been intriguing on the king's behalf during early $164_{1}$, and his use of the term raises the intriguing possibility that Suckling and his fellow-conspirators may have proudly embraced the word 'cavaliers' to describe themselves before that word was taken up and deployed against them by the anonymous satirist: that it was the king's friends, not his enemies, in other words, who had first invested the hitherto neutral word 'cavalier' with a specific partisan significance. Whatever the case, there is no evidence to suggest that this lexical innovation was widely remarked on at the time. Instead, the new, political, meaning with which the familiar term 'cavalier' had been freighted seems to have gone largely unnoticed for some months to come. In December 1641, however, this convenient new party-label in embryo - if we may term it thatwas first seized upon and then, within days, brought to a far wider public than ever before during the course of a second proto-parliamentarian hate-campaign mounted against a second ex-army officer: this time, Thomas Lunsford.

How had Lunsford found himself in the frame? Once again, political developments in London provide the key. In October 1641 , a huge rebellion took place in Ireland, when its Catholic inhabitants rose up in arms against their British Protestant neighbours. The king's enemies in parliament, desperate to keep English public opinion on their side, now started to hint that Catholic plotters in England - including, perhaps, the king's own wife - had secretly encouraged the Irish rebellion.53 At the same time, they encouraged their supporters in London to stage mass demonstrations against those they termed 'papist lords

$5^{\circ}$ See Wilcher, Suckling, pp. 117, 231, 245, 267, 281-97, and 335; and J. Suckling, 'Brennoralt: a tragedy', in Anon., ed., Fragmenta aurea: a collection of all the incomparable peeces written by Sir John Suckling (London, 1646), sig. A2r.

$5^{1}$ As Wilcher notes, Suckling had already been mockingly described as an 'exquisite Cavalier' by the play-wright Richard Brome in either 1639 or 1640 ; see Wilcher, Suckling, p. 353 .

$5^{2}$ See J[ohn] M[ennes] and Ja[mes] $\mathrm{S}[\mathrm{mith}]$, Musarum deliciae: or the muses recreation (London, $165_{6}^{6}$ ), p. 8; and Raylor, Literary culture, pp. $170-1$.

53 For the rumours that the queen had helped to inspire the Irish rebellion, see C. M. Hibbard, Charles I and the popish plot (Chapel Hill, NC, 1983), pp. 213-14. 
and bishops'.54 Soon the capital was in ferment, and Charles, fearful that London might soon slip completely out of his control, once again sought to gain firm control of the Tower: this time by easing out its long-term lieutenant, and replacing him with an officer whom he could trust. The man whom Charles chose for the job was Thomas Lunsford, who, following the disbandment of the English army, in September, had taken up his station in London - along with many other former officers - in the hope of securing fresh military employment from the crown. 55 Why the king should have selected Lunsford, of all people, to hold this key post is an intriguing question. The royalist historian Edward Hyde states that Lunsford was recommended to Charles by the courtier Lord Digby, but - as Hyde disliked Digby, and took every opportunity to do him down - his testimony must be regarded with some suspicion. $5^{6}$ It is conceivable that Hyde was trying to conceal the extent to which Charles himself had been responsible for the fateful decision. 57 Whatever the case, it was a remarkable promotion for Thomas. But he was not to enjoy his new position for long.

\section{V}

Charles appointed Lunsford as lieutenant of the Tower on 22 December - and at once unleashed a storm of protest. $5^{8}$ It was already common knowledge among the members of the political elite that Lunsford was not averse to physical violence, to say the very least, that he was heavily in debt, and that he was financially rapacious (we may note that, just six months before, Lunsford's own sister had petitioned the Lords for the restoration of her inheritance, which, she alleged, her brother had appropriated during the time of her minority). 59 Now the king's enemies clearly did everything they could to convince ordinary Londoners that the new lieutenant-who had, after all, served in the French king's army - was in league with 'popish plotters', too, and that his appointment foreshadowed a Catholic attempt on London itself. ${ }^{60}$ The wildest

\footnotetext{
54 For the role played by 'oppositionist' MPs in encouraging popular protests in the capital, see R. Ashton, The English Civil War: conservatism and revolution, I603-I649 (London, 1978), pp. 150-1; Braddick, 'Prayer book', pp. ${ }^{126-30}$; and Manning, English people, pp. 107-10 (quotation at p. 110).

55 On the ex-army officers who came to London seeking both their arrears of pay and fresh military employment in late 1641 , see Clarendon, History, I, p. 456; and - for a helpful, if unsympathetic, modern discussion - Manning, English people, pp. 132-4.

$5^{6}$ Clarendon, History, I, p. 478. On Digby, see R. Hutton, 'Digby, George, second earl of Bristol (1612-1677)', in ODNB, pp. 143-6.

57 As Richard Cust has well observed, the decision to appoint Lunsford was a 'grotesque misjudgement' on the king's part, see Cust, Charles I and the aristocracy, p. 260.

$5^{8}$ For the date of Lunsford's appointment as lieutenant of the Tower, see CSPD, ${ }_{1} 64{ }^{I-I} 643$, p. 210 ; and BL, E.201 (4), Diurnall occurrences (London, 20-7 Dec. 1641), sig. A3v.

59 For Lunsford's financial affairs and his sister's petition, see The Parliamentary Archives, $\mathrm{HL} / \mathrm{PO} / \mathrm{JO} / 1 \mathrm{O} / 1 / 114$, fo. $8 \mathrm{o}$; and $\mathrm{HL} / \mathrm{PO} / \mathrm{JO} / 1 \mathrm{o} / 1 / 59$, fo. 149 .

${ }^{60}$ For a specific reference to the fact that Lunsford 'hath been Colonell under the King of France', see BL, E.181 (9), A bloody masacre [sic] plotted by the papists (London, 1641), p. 3 .
} 
rumours about Lunsford were soon flying abroad. Nehemiah Wallington, a London tradesman, noted in his journal at this time that 'on December the XXIII the [old] leftenant of the Tower...was put out, and...that wicked bloody Coranel Lounsee [sic]...put in' his place. 'I did here [that] he was an outlawed man, and that he had killed two and was put into Newgate', Wallington went on, breathlessly,

and [that] he broke forth of Newgate and fled beyond sea. And now he was come againe to have the charg of the strength of our citty, that...he might batter downe our houses... [with the cannon of the Tower], insomuch that now...grat companies [of people] did goe up unto Westminster [to protest] unto the parliament. ${ }^{61}$

As these words make clear, within hours of his appointment Lunsford had been transformed from a relatively obscure ex-army officer into public enemy number one - at least as far as the godly citizens of London were concerned and this was only the beginning of his descent into infamy. On 23 December, a petition against Lunsford's appointment signed by eighty-six influential Londoners - many of them politico-religious radicals - was presented to the Commons. $^{62}$ After considering this petition, the MPs sent a message to the Lords, in which they claimed, inter alia, that 'while...[Lunsford] was in the king's army...he never came to...church': a claim which other evidence shows to have been untrue, and which was clearly intended to open the way for Lunsford to be 'smeared with the popish label' as other royal servants had been before him. ${ }^{6}$ The MPs then asked the Lords to join with them in requesting the king to dismiss Lunsford forthwith. ${ }^{6} 4$ The Lords refused to comply, and, upon being presented with another, still more strongly worded, request for immediate action, on Friday 24 December, returned answer that they would consider the matter on the following Monday. ${ }_{5}^{6}$ As a result, friction grew between the two houses - and, indeed, between those peers who had voted to defer consideration of Lunsford's case and those who had not. ${ }^{66}$ Meanwhile, even the king's own supporters were becoming alarmed by the passions which Lunsford's appointment had unleashed. ${ }^{67}$ Accordingly, Charles agreed to

61 D. Booy, ed., The notebooks of Nehemiah Wallington, I6I 8-i 654: a selection (Farnham, 2007), p. 133 .

${ }^{62}$ For the text of this petition, see Rushworth, Historical collections, Iv, p. 459; and, for a revealing discussion of the signatories, see K. Lindley, Popular politics and religion in Civil War London (Aldershot, 1997), pp. 104, $138-45$.

63 See Journal of the House of Commons (CJ), II, I640-I643, p. 353 (first quotation); W. H. Coates, ed., The journal of Sir Simonds D'Ewes: from the first recess of the Long Parliament to the withdrawal of King Charles from London (Yale, CT, 1962), pp. 340, 342-3; and Hibbard, Popish plot, pp. $17,130-1,15^{\circ}$ (second quotation), and 195 .

64 CJ, II, p. 353 .

65 Ibid., pp. 353-7; Journal of the House of Lords (LJ), Iv: I629-I642, pp. 486-8; Coates, ed., D'Ewes, pp. 339-48, and Rushworth, Historical collections, IV, pp. 459-6o.

66 See Cust, Charles I and the aristocracy, p. 261.

67 BL, E.201 (5), Diurnall occurrences (London, 27 Dec. $164_{1}$ to 3 Jan. 1642), sig. A2r. 
replace Thomas with a less controversial officer. ${ }^{68}$ By the evening of 26 December, Lunsford had relinquished the post to which he had been appointed just four days before, his departure underlining the king's growing powerlessness in the face of popular pressure. ${ }^{69}$

Unaware of Lunsford's dismissal, large crowds of protestors gathered at Westminster on 27 December and soon began to barrack the king's supporters especially the supposedly 'popish' bishops - as they made their way to the House of Lords. $7^{\circ}$ Infuriated by the demonstrators' continual chanting of 'No bishops!' and by their menacing demeanour, a former army officer, Captain David Hyde, now 'began to bustle' in his turn, twice drawing his sword upon the protestors who had gathered in Westminster Hall and threatening to do them some hurt. $7^{1}$ Hyde was swiftly disarmed and apprehended, but soon afterwards Lunsford himself arrived on the scene, with some other ex-army officers, having apparently been summoned to attend the House of Lords. ${ }^{72}$ Quite what happened next we may never know: some contemporary sources claim that Lunsford and his friends now drew their swords and launched a completely unprovoked attack on the demonstrators, while others paint a rather different picture, insisting that 'at their returne back though the Hall, [the officers], fearing to be assaulted by the Prentises, drew their swords to defend themselves from offence'.73 What is certain is that a fierce fight now ensued in Westminster Hall: a fight which saw a number of people being 'cut' and otherwise injured, and which eventually resulted in Lunsford and his companions being driven from the scene. 74

68 Ibid.; and Lindley, London, p. 106.

69 See BL, E.2O1 (5), sig. A2r; and Clarendon, History, I, p. 448.

$7^{\circ}$ Rushworth, Historical collections, IV, p. 463 .

$7^{1}$ On David Hyde, see Rushworth, Historical collections, Iv, pp. 463-4 (quotations at p. 463); BL, E.181 (16), The Scots loyaltie (London, 1641), sigs. A2r-A2v; E.181 (9), p. 4; Newman, Royalist officers, p. 208; and Roy, 'Royalist reputations', p. 104.

$7^{2}$ Rushworth, Historical collections, Iv, pp. 463-4; BL, E.181 (16), sigs. A2v-A3r; BL, E.181 (9), pp. 3-4; BL, E.201 (5), sig. A2v; BL, Burney Collection, vol. 8* (4), Diurnall occurrences in parliament from the 27 of December to the $2 d$ of Januarie 1641 , p. 2; and BL, Burney Collection, vol. 8* (5), Diurnal occurrances, touching the dayly proceedings in parliament...27 December I 641 to 3 January [I642], p. 2. I am most grateful to Qona Wright of the rare books and reference service at the British Library for providing me with several transcripts from the latter pamphlet, which is too fragile to be produced for readers.

73 See, for example, BL, E.181 (9), p. 4; and BL, Burney Collection, vol. 8* (5), p. 2 (quotation).

74 For the affray at Westminster Hall, and Lunsford's central role in it, see LJ, IV, pp. 49o-3; Coates, ed., D'Ewes, p. 353; CSPD, I64I-I643, p. 217 ; HMC, Manuscripts of Lord Montagu of Beaulieu (London, 19oo), pp. 137-8; BL, E.181 (9), pp. 3-5; BL, E.181 (16), sigs A2v-A3r; BL, Burney Collection, vol. 8* (4), p. 2; BL, Burney Collection, vol. 8* (5), p. 2; Booy, ed., Wallington, p. 133; BL, E.241 (1), An exact collection of all... [the] remarkable passages between the kings... majesty and his high court of parliament (London, Mar. 1643), p. 202; BL, E.45 (2), 'W. L.', A medicine for malignancy (London, c. 2 May 1644), pp. 10, 27; and Rushworth, Historical collections, IV, p. 464 . 
This was the very first armed clash to have occurred between the most ardent supporters of the parliament - 'the roundheads', as the puritan apprentice-boys were christened on that same day by David Hyde - and the most ardent supporters of the king - 'the cavaliers', as Lunsford and the former officers about him were being openly referred to by their enemies within days, if not hours, of the affray. 75 Thus, the partisan soubriquet which had initially been applied to Suckling and his confrères by a few literary men in May or June had gone on to be applied to Lunsford and his associates by a thousand angry mouths in December-and would soon go on to be applied to Charles's supporters across the entire kingdom during the months to come. (Significantly enough, one of the very first proto-parliamentarian pamphleteers to assail Lunsford in print made a direct comparison between him and Suckling, asserting that 'he is so deboyst a man, that he is generally reported to be as lascivious even as Sir John Suckling', providing clear evidence that Sir Thomas was now being portrayed as Sir John's direct successor. ${ }^{6}$ ) If he was not, quite, 'the first cavalier', then, Lunsford was certainly the first notorious cavalier.77 And his name was soon to become more infamous still.

On 28 December, Lunsford was knighted by the king-a clear public statement of the fact that, while Charles had been forced to remove Lunsford from his position as lieutenant of the Tower, he still retained every confidence in him. $7^{8}$ Over the following days, Sir Thomas and his fellow

75 For Hyde's 'first miniting of that term or compellation of Round-Heads', see Rushworth, Historical collections, Iv, p. $46_{3}$. C. V. Wedgwood claims that it was two days later-during the skirmish of 29 Dec. - that 'the offensive epithet' of 'Cavalier' was 'for the first time freely bandied about', see King's war, p. 53. She may be right, but contemporary evidence on this point is frustratingly vague, and it seems more likely that it was the fight at Westminster Hall on 27 Dec. which first saw the term entering the popular political lexicon. For allusions to Lunsford and his followers as 'Cavaliere' or 'Cavaliers' in proto-parliamentarian pamphlets published in the immediate aftermath of the affrays of 27-9 Dec., see BL, E.181 (16) (London, undated, but probably c. 29 Dec. 1641), sig. A2v; BL, E.181 (21), A true relation of the most wise and worthy speech made by Captain Ven (London, undated, but probably c. 31 Dec. 1641), sig. A2r; BL, Burney Collection, vol. 8* (4), Diurnall occurrences in parliament from the 27 of December to the $2 d$ of Januarie ${ }^{6} 64 \mathrm{I}$, p. 2; BL, E.131 (16), Matters of note made known to all true Protestants (London, undated, but probably c. 8 Jan. 1642), title-page; BL, E.201 (6), Diurnall occurrences in parliament (London, 2-10 Jan. 1642), p. 3; and BL, E.181 (31), A true relation of the unparaleld breach of parliament (London, c. 11 Jan. 1642), title-page.

$7^{6}$ BL, E.181 (9), p. 3.

77 In the immediate aftermath of the disturbance at Westminster Hall, Lunsford and Captain Hyde were summoned to attend the House of Commons on the morning of 28 Dec., see CJ, II, p. 357; and CSPD, $I_{64}{ }^{-1}{ }_{1} 643$, p. 213 . There is no evidence to suggest that they did so, see Coates, ed., D'Ewes, p. 354 n. 28.

$7^{8}$ Russell, Fall, p. 441. See also W. A. Shaw, The knights of England, II (London, 1906), p. 211. Lunsford was also said to have been given a pension of $£_{5}$ oo per annum by the king at this time, see CSPD, $164 I^{-1} 643$, pp. $215^{-16}$; and $H M C$, Beaulieu, p. $13^{8 .}$ 
ex-officers - who had by now volunteered their services to guard the king's palace at Whitehall from the demonstrators - took part in further brawls with the apprentices who were continuing to mill around Westminster, while on 4 January 1642 they formed the core of the party of armed men who accompanied Charles I when he set out on his doomed attempt to arrest his chief critics in the House of Commons. 79 The MPs escaped, of course, while Londoners were outraged by the king's resort to naked force. As soon as word of what had happened got out, thousands rose in angry protest, and a few days later, Charles abandoned his capital to his enemies. $^{80}$ The king retreated to Hampton Court, whence he was followed by Lunsford and the other former officers, and on 12 January Sir Thomas allegedly made an attempt to raise some military forces at the neighbouring town of Kingston-upon-Thames. ${ }^{81}$ Although nothing came of this supposed plan, it caused panic in London, and encouraged hysterical denunciation of Lunsford in the popular press. Already, writers allied to the king's opponents had produced a series of printed pamphlets which openly declared Lunsford to be a 'papist', termed him a second Guy Fawkes and alleged that he was plotting to deliver London into the hands of the Irish Catholics. $^{82}$ Following the 'hurly burly' at Kingston, many more pamphlets attacking Lunsford appeared, one of them presenting him as a Catholic villain who was bent on 'cut[ting] Protestants throates'. ${ }^{3}$ Thus, the gentleman-soldier from Sussex-violent and quarrelsome, without doubt, but hardly a monster - had been transformed by the London pamphleteers into a fearsome fiend, dripping with human gore.

Nor was it through words alone that such terrifying notions were spread, for several vivid pictures of Lunsford were also published in 1642: pictures which

79 For the decision of Lunsford and his fellow ex-officers to constitute themselves as a royal guard, see Clarendon, History, I, p. 456; Calendar of state papers, Venetian (CSPV), I640-I642, p. 272; and CSPD, I $64 I_{-1643}$, p. 217 . For a reference to the 'hundred soldier-like men' who had 'gathered to Lunsford' at Whitehall, see HMC, Beaulieu, p. 138. For Lunsford's involvement in the skirmish of 29 Dec., see A. Fletcher, The outbreak of the English Civil War (London, 1981), p. 172; and, for the skirmish more generally, see BL, E.201 (5), sig. A3v; CSPD, $I_{64}{ }^{-}$ ${ }_{1643}$, pp. 215-17; and HMC, Beaulieu, p. 138. For the former officers' presence at the attempted arrest of the Five Members, see HMC, Beaulieu, p. 141; CSPV, I640-I642, p. 276; BL, E.181 (31), title-page and pp. 1-2; and BL, E.201 (6), pp. 1-3.

8 o Adamson, Noble revolt, p. 499.

${ }^{81}$ For the affair at Kingston, see CJ, II, pp. 371-5; BL, E.2O1 (8), Diurnall occurrences of the heads of all the severall proceedings (London, $10-17$ Jan. 1642), sig. A2v; W. H. Coates, A. S. Young, and V. Snow, eds., The private journals of the Long Parliament (London, 1982), pp. 40, $43^{-4}, 4^{6}, 5^{\mathrm{O}}, 5^{1}, 5^{8,} 7^{1-2}$; and $\operatorname{CSPV},{ }_{1} 640-1642$, p. 285 .

${ }_{82}$ See, for example, BL, E.131 (9), A terrible plot against London and Westminster (London, 1642), title-page and sig. A2v; BL, E.132 (10), A letter of high consequence (n.p., 1642); and BL, E.132 (26), The parliament's care for the citie of London (n.p., 1642). I have found no independent evidence to suggest that Lunsford was a Catholic.

${ }^{83}$ See, for example, BL, E.131 (15), A true relation of the late hurliburly at Kingston...caused by Collonell Lundsford (n.p., 1642), at p. 1; and BL, E.131 (21), To the king's most excellent majestie (London, 1642), title-page. 
undoubtedly did a great deal to increase his notoriety. ${ }^{84}$ One of these depicts a fierce-looking man with a sword - helpfully labelled 'Colonell Lunsford' - advancing purposefully on a group of civilians who flee in terror before him (Figure 2). This woodcut-which, we may note, shows Lunsford at the head of 'a great rout of ruffi[a]nly Cavaleires' - is clearly intended to represent the affray at Westminster Hall. ${ }^{85}$ The other image is more striking still and depicts Lunsford as an arrogant, posturing soldier, wearing a sword and carrying a pike (Figure 3). ${ }^{86}$ Behind him, houses are going up in flames while women are being ravished-a reference to the brutal, continental style of warfare which, the supporters of parliament claimed, 'cavaliers' like Lunsford would soon introduce to England. The contrast between this image and that of the young fops of the 'Sucklington Faction' which had appeared just a few months before is marked, and demonstrates how Lunsford's reputation was now being exploited in order to inject a new sense of brutish menace into the evolving archetype of 'the cavalier'. Beneath the picture is a short verse, which is clearly intended to represent Lunsford's own words: 'Ile helpe to kill, to pillage and destroy', 'Lunsford' declares:

All the opposers of the prelacy [i.e. the bishops],

My fortunes are growne small, my freinds are less,

I'le venter therefore [my] life to have redress,

By picking, stealing, or by cutting throates,

Although my practice crosse the kingdoms votes. ${ }^{87}$

Here, then, it was suggested that Lunsford would do whatever it took to recover his personal fortunes, even if this meant flying in the face of his countrymen's wishes, as expressed by their representatives in parliament.

Even as these images of Lunsford were circulating across the kingdom, Lunsford himself was helping to kick-start the royalist war-effort. There were many who were prepared to rally to the king in his struggle with his enemies in parliament and by October 1642 Charles had gathered an army of some 10,0oo men. ${ }^{88}$ Lunsford was prominent among them and when the royalist and parliamentarian armies finally met in the first battle of the Civil War, at Edgehill, Sir Thomas marched into action at the head of his own infantry

\footnotetext{
${ }^{84}$ In this respect, Lunsford's case parallels that of Prince's Rupert's supposed witch-dog, 'Boy': another notorious royalist whose fame owed much to his depiction in a series of graphic satires, see M. Stoyle, The black legend of Prince Rupert's dog: witchcraft and propaganda during the English Civil War (Exeter, 2011), passim, especially p. 8.

$8_{5}$ BL, E.1 16 (49), All the memorable $\mathcal{E}$ \% wonder-strikinge parliamentary mercies (n.p., c. 14 Sept. $1642)$, unpaginated.

${ }^{86}$ BL, E.669, f.6 (71), Come freind, array your selfe (single-sided broadsheet, n.p., n.d., but probably published in summer $1^{1642}$ ). This image is helpfully discussed in F. G. Stephens, Catalogue of political and personal satires... in the British Museum, I: 1320-I689 (London, 1879), pp. $246-8$.

87 BL, E.669, f.6 (71).

88 R. Hutton, The royalist war effort, ${ }_{1} 64^{2-1} 646$ (London, 1982), p. 28.
} 


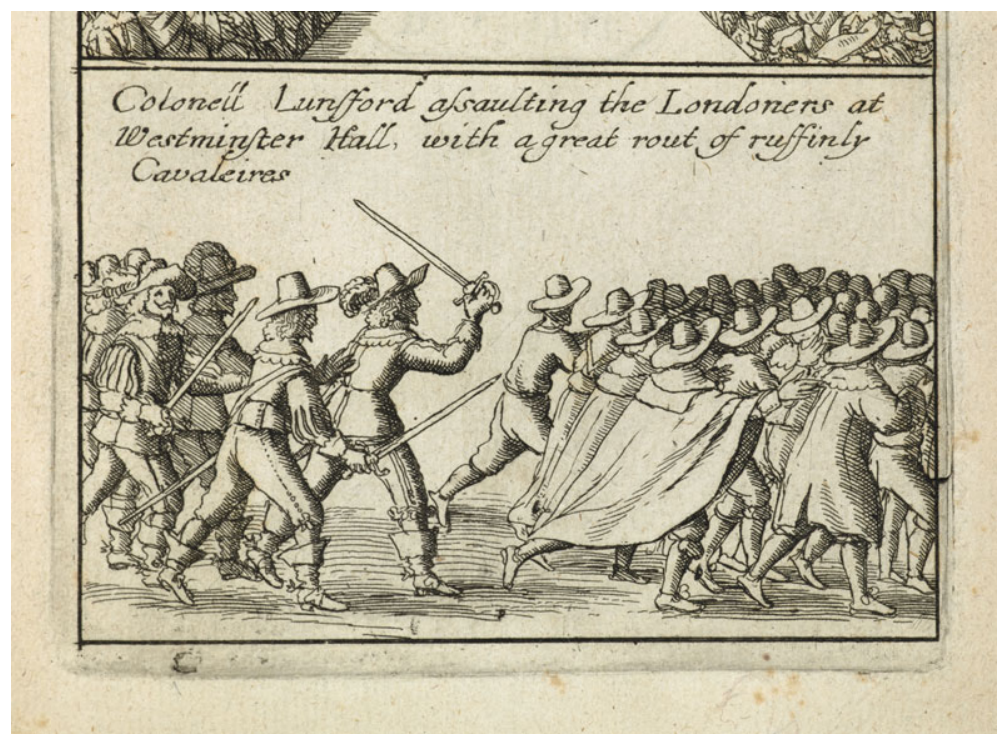

Fig. 2. 'Colonell Lunsford assaulting the Londoners at Westminster Hall with a great rout of ruffinly Cavaleires', detail from All the memorable and wonder-strikinge parliamentary mercies, c. 14 Sept. 1642. () British Library Board, E.1 16 (49).

regiment. ${ }^{89}$ Courageous as ever, he hurled himself into the thick of the fighting-only to be captured and subsequently imprisoned, in Warwick Castle. $9^{\circ}$ For the next year, Sir Thomas remained a captive, and-although he was later to be exchanged for three captured parliamentarian officers, at the king's own insistence - he was never again to stand at the storm-centre of English politics as he had briefly done during the tumultuous Christmas season of $1641-2.9^{1}$

\section{I}

As Lunsford was led through the great vaulted gateway of Warwick Castle, the soldiers who would henceforth serve as his gaolers must have been keenly aware of the heavy burden of responsibility which parliament had placed on

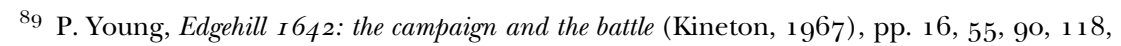
219-21.

$9^{\circ}$ Ibid., pp. 281, 314; BL, E.1 27 (29), The examination of Colonell Lunsford...taken in the fight at Kineton (London, 19 Nov. 1642); W. Hamper, ed., The life, diary and correspondence of Sir William Dugdale (London, 1827), p. 66; and P. Styles, ed., 'The genealogie, life and death of the right honourable Robert Lorde Brooke', Publications of the Dugdale Society, 31 (1977), p. 183.

$9^{1}$ For Lunsford's exchange in May 1644, see BL, E.5o (6), Mercurius Aulicus (Oxford, 12-18 May 1644), p. 986; and Hamper, ed., Dugdale, p. 66. For a letter of 14 Apr. 1644 from Sir Edward Nicholas stressing that the king would sanction no exchange of other royalist prisoners until Lunsford had been released, see G. N. Godwin, The Civil War in Hampshire (London, 1904), p. 198. 


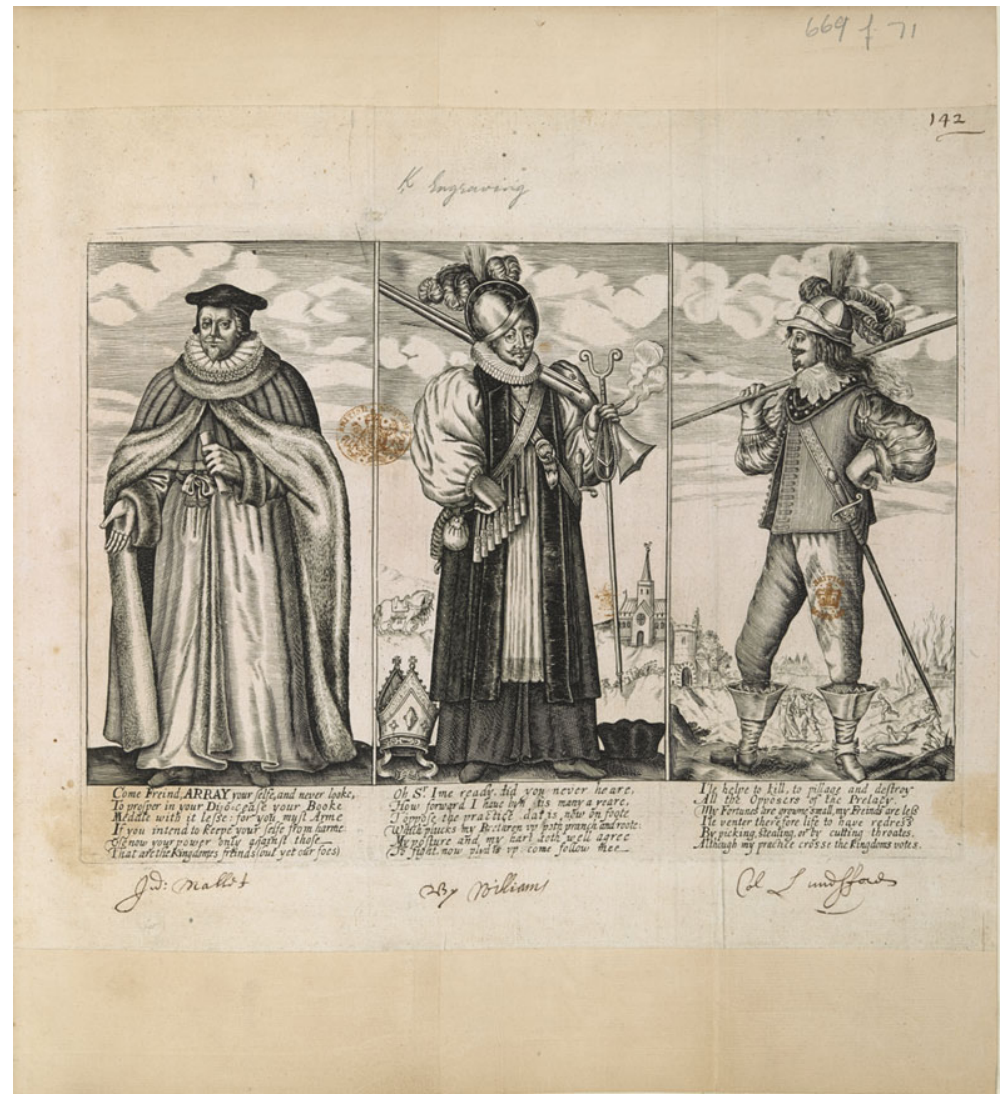

Fig. 3. Come freind, array your selfe, a hostile depiction of three prominent supporters of the king-from left to right, Judge Thomas Mallet, Archbishop John Williams, and Colonel Thomas Lunsford, 1642. (c) British Library Board, E.669, f.6 (71).

their shoulders, for they were now charged with the safe-keeping of a man who, throughout much of $164^{2}$, had been the most infamous cavalier in England. But did Lunsford's new gaolers also believe themselves to have a cannibal on their hands? Lunsford's alleged cannibalism is the single thing for which he is nowadays best remembered-but although some modern historians have gone so far as to portray him as the Hannibal Lecter of his day, in the popular imagination at least, noting that he was said 'to roast the flesh of babies'; that he was 'accused of murdering and eating children'; and that 'both sides believed him guilty of cannibalism' - diligent research has so far failed to unearth a single contemporary allusion to man-eating on Sir Thomas's part until after his capture at Edgehill. $9^{2}$ The earliest references to

$9^{2}$ C. Hibbert, Cavaliers and roundheads: the English at war, I642-1649 (London, 1993), p. 30; T. Royle, Civil War: the wars of the three kingdoms, I638-I660 (London, 2005), p. 154; and 
Lunsford's supposed anthropophagical appetites which have been identified, moreover, do not originate from the place we might expect - from the parliamentarian presses in London - but rather from Ireland, and from the king's wartime capital of Oxford.

The single Irish reference, which may well be the earliest of them all, appears in a pamphlet printed at Kilkenny in December 1642 , where - in the course of a disquisition on the war in Ireland and on the atrocities which had been attributed to the Irish rebels by their English opponents - the anonymous author remarked 'that [it] is indeed an ordinary thing in all wars to raise such reports, to make the enemy odious, although no truer than that Colonel Lunsford did eat children about Kingston'.93 These words not only suggest that supporters of the parliament had, indeed, claimed that Lunsford ate children, but also indicate - through the specific reference to Kingston - that the rumour had begun at the very height of the panic which had raged around Sir Thomas in January 1642 , just as we might expect.94 They also reveal, of course, that the Irish author of the pamphlet was himself entirely dismissive of such stories.

The references which appeared in royalist publications in England were just as dismissive, but were couched in a mischievous, mocking way, by authors who plainly derived enormous amusement from the suggestion that their foes might have been gullible enough to believe that Sir Thomas was a cannibal. This was true, for example, of the author of a satirical verse who claimed that, after the battle of Edgehill, parliamentarian supporters had falsely reported that Lunsford had been killed, and that:

The Post, that came from Banbury,

Riding in a Blew Rocket [i.e. cloak], He swore he saw, when Lunsford fell A Child's Arm in his Pocket.95

The suggestion here was clearly that the parliamentarians believed Lunsford to be in the habit of carrying severed limbs of children about his person - just in case he should happen to feel hungry during the course of the day. And around Christmas 1642 , the royalist poet John Cleveland similarly poked fun at the king's enemies, when he claimed that they were convinced that Prince

C. Carlton, Going to the wars: the experience of the British Civil Wars, ${ }_{16}{ }_{3}^{8}{ }_{-1} 65 I$ (London, 1992), p. 43 .

93 A. Clarke, ed., 'A discourse between two councillors of state', Analecta Hibernica, 26 (1970), p. 172 .

94 For another, much later, suggestion that the rumours about Lunsford eating children had originated in the wake of the affair at Kingston, see W. Howell, Medulla historiae Anglicanae, being a comprehensive history of the... monarchs of England (London, 1679), p. 467 .

95 The earliest version of this verse which I have so far managed to locate appears in Anon., The works of Mr John Cleveland (London, 1687), p. $3^{82}$. 
Rupert's dog commonly feasted on 'the scraps which Lundsford makes, whose picture feeds upon a child in st[e]aks'. $9^{6}$

Cleveland's comment is an especially intriguing one, because it appears to suggest that parliamentarian polemicists had gone so far as to produce a graphic satire depicting Lunsford as a child-eating monster. Could this possibly have been true? Or had Cleveland simply invented the story in order to pour scorn on his enemies? The fact that no such image now survives at once inclines us towards the latter conclusion, but we should not dismiss Cleveland's assertion on these grounds alone, for absence of evidence is not evidence of absence, and the poet's phraseology does seem to imply that he was speaking of an image which he himself had seen. Nor can there be any doubt that the king's enemies had for some time been exploiting the subject of cannibalism - a subject which, then as now, possessed the capacity to arouse exceptionally strong feelings of revulsion and fear - to their own advantage.97 During the late 1630 , several horrific pamphlets had been published in London which detailed the torments being inflicted on the inhabitants of Germany in the Thirty Years War. Included in this terrifying atrocity literature were reports of Croatian soldiers not only feeding their dogs with human flesh, but even eating people themselves. $9^{8}$ As Barbara Donagan has shown, stories like these were 'widely circulated, luridly illustrated, and uncritically received' during the final years of the personal rule, and when, in late $164^{1}$, the king's domestic opponents sought to identify ways of maximizing the horrors of the Irish rebellion in order to convince the English people to rally to them in their struggle against armed Catholic 'conspiracy', they did not have far to seek.99 Soon, a flood of new atrocity pamphlets was pouring off the London presses: pamphlets which excoriated the Irish rebels in words and images which were frequently very reminiscent of those which had been deployed in the earlier German horror-stories.

Significantly, several of these publications had compared the Irish rebels to 'Canniballs'. ${ }^{\text {oo }}$ And more significant still, in the context of the present discussion, is the fact that, by the end of 1641 if not before, proto-parliamentarian polemicists had dared to suggest that Charles I's own archbishop, William Laud, possessed a liking for human flesh. As Helen Pierce has shown in an important article, Laud-denounced as a crypto-papist and imprisoned in the

$9^{6}$ See J. Cleveland, 'To P. Rupert', in The character of a London diurnall: with severall select poems (n.p., 1647), p. $5^{1}$; and-for a discussion of the poem and the date at which it was originally composed - Stoyle, Black legend, pp. $45^{-9}$.

97 See R. Tannahill, Flesh and blood: a history of the cannibal complex (London, 1975), pp. 32, 34; and F. Lestringant, Cannibals (Cambridge, 1997), pp. 9, 17, 22-3, 29, 30, and 7 o.

$9^{8}$ See Anon., The warnings of Germany (London, 1638 ), p. $5^{\mathrm{O}}$; and P. Vincent, The lamentations of Germany (London, $\left.163^{8}\right)$, p. 3 o.

99 B. Donagan, 'Halcyon days and the literature of war: England's military education before 1642', Past and Present, 147 (1995), pp. 73-8, at p. 77.

${ }_{100}$ See, for example, Wing W42, Anon., Good and bad newes from Ireland (n.p., 1642), sig. A4r; and Wing C6824, J. Cranford, The teares of Ireland (London, 1642), p. 78. 


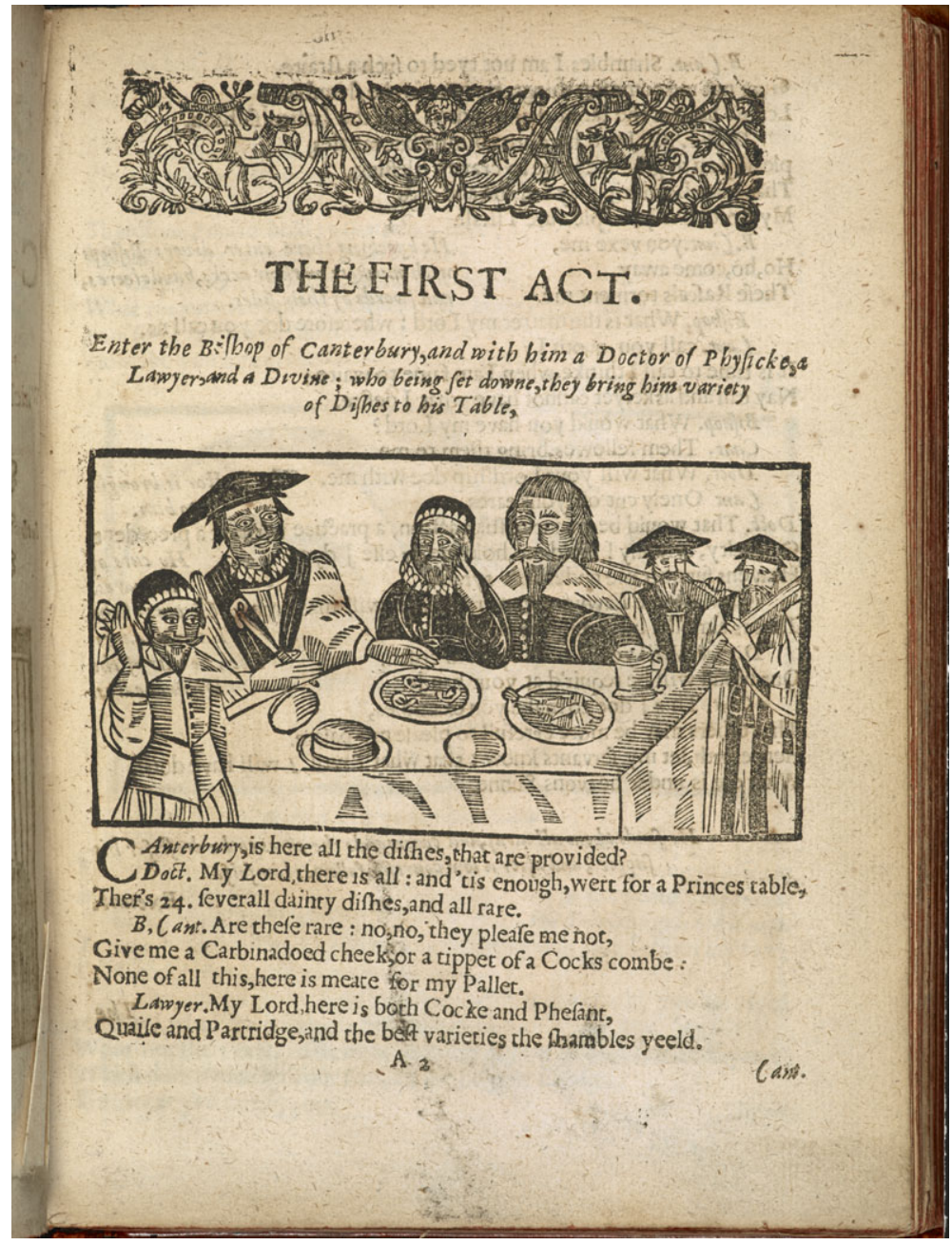

Fig. 4. Archbishop Laud feasting on the severed ears of puritans, detail from A new play called Canterburie his change of diot, [Nov.?] 1641. (C) British Library Board, E.177 (8).

Tower in March $164^{1}$ - had thereafter been subject to an unprecedented series of vitriolic printed attacks. ${ }^{101}$ Among the many absurd accusations which were levelled against Laud at this time was the charge that he had feasted on the severed ears of the 'puritan martyrs', Prynne, Burton, and Bastwick - and indeed in a satirical play, published in late 1641 , there had appeared a

${ }^{101}$ H. Pierce, 'Anti-episcopacy and graphic satire in England, 1640-1645', Historical Journal, 47 (2004), pp. 809-48. 


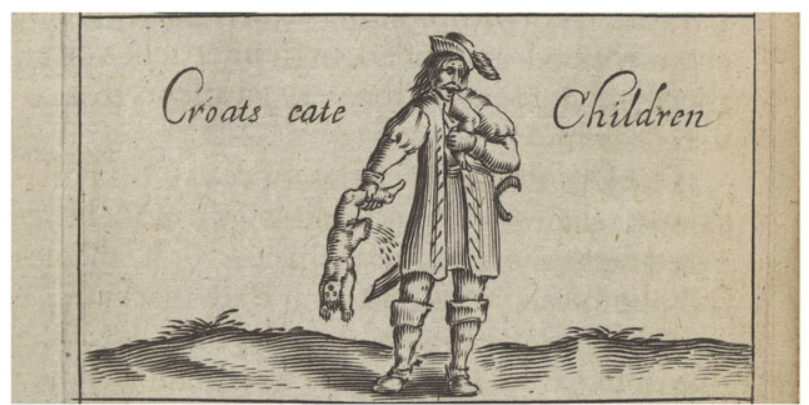

Fig. 5. 'Croats eate Children', detail from P. Vincent, The Lamentations of Germany, 1638. (C) Wellcome Library, London.

woodcut of the three men's ears being served up for the archbishop's delectation (Figure 4$).{ }^{102}$

The claim that Laud had devoured his enemies' ears was clearly made in bitter jest. Even so, the fact that a graphic satire alleging cannibalism on Laud's part is known to have been published in late ${ }^{16} 4_{1}$ does make it easier to credit the notion that a graphic satire alleging cannibalism on Lunsford's part might conceivably have been published in early 1642. Such an image would, of course, have possessed enormous contemporary resonance-at once associating the king's 'cavaliers' with the horrors visited on Germany and Ireland - and would therefore have been a highly desirable image to put into public circulation from a parliamentarian point of view. It is fascinating to note, moreover, that The lamentations of Germany-one of the most influential of the German atrocity pamphlets published a few years before - had contained a gruesome woodcut of a Croatian soldier eating a child's leg (Figure 5). ${ }^{103}$ This image is so reminiscent of the one Cleveland describes in his poem that it is hard not to suspect that he had had it in mind when he wrote the relevant lines. Yet, if this was indeed the case, had Cleveland simply remembered the image of the Croatian soldier-ogre from the earlier pamphlet and then falsely claimed that the parliamentarians had circulated similar depictions of Lunsford? Or had he genuinely seen a doctored version of that original image: one which had been re-worked by parliamentarian polemicists in order to suggest that Lunsford dined on child-flesh? We may never know the truth - but Cleveland's literary intervention clearly had a powerful effect.

Over the following years, it became an article of faith among the king's supporters that the parliamentarians had announced to the world that Lunsford ate children, and the tale was endlessly repeated. ${ }^{104}$ As late as 1668 , for

102 Ibid., p. 833; and BL, E. 177 (8), Anon., A new play called Canterburie his change of diot (n.p., Nov. [?] 1641), sig. A2r.

103 Vincent, Lamentations, p. 27.

104 See, for example, BL, E.97 (10), Mercurius Aulicus (Oxford, 2-9 Apr. 1643), p. 180; BL, E.669, f.1 1 (82), F. Wortley, A loyall song of the royal feast (single-sided broadsheet, n.p., 16 Sept. 
example, a royalist writer remarked that 'Sir Thomas was feigned by the Brethren [i.e. the puritans] a devourer of Children', while in the third volume of his celebrated anti-puritan satire Hudibras, first published in 1678 , Samuel Butler made mocking reference to the terror which Lunsford had apparently inspired in the hearts of youthful Londoners. ${ }^{105}$ Much later still, the story was taken up and elaborated upon by Sir Walter Scott in his great Civil War novel Woodstock, first published in $1826 .{ }^{106}$ Woodstock went on to be an enormous success, and no doubt this was the chief reason that the image of Lunsford as a 'cannibal cavalier' subsequently attained such widespread currency during the nineteenth century. ${ }^{107}$ Whether anyone with any sort of authority on the parliamentarian side ever did really claim that Lunsford ate children, however let alone whether large numbers of ordinary people really believed that he didmust surely remain open to doubt.

What does not remain open to doubt is that, for a brief moment in $164^{1-2}$, Thomas Lunsford stood at the very centre of the developing political conflict, and that, as a result of the determination of parliament's supporters still further to blacken his already woefully tarnished name, he was transformed into a popular bogeyman: the first in a long line of royalist officers on whom this transformation would subsequently be wrought. ${ }^{108}$ Sir Thomas was to live on for ten years after his capture at Edgehill, but nothing he did thereafter would substantially alter the public perception of him which had become established during $1641-2 .{ }^{109}$ His place in history was already assured: as the first man in England to be widely denounced by his political opponents as a 'cavalier' and thus -in some respects, at least-as the inspiration for a legend.

\footnotetext{
1647); and Anon., Rump: or an exact collection of the choycest poems and songs relating to the late times ( 2 vols., London, 1662 ), I, p. 65 .

${ }^{105}$ Lloyd, Memoires, p. $5^{81}$; and S. Butler, Hudibras: the third and last part (London, 1678), p. 175 .

106 Scott, Woodstock, II, pp. $214^{-27}$.

${ }^{107}$ It was probably Scott's allusions to Lunsford in Woodstock which inspired Steinman-Steinman to write his pioneering historical account of Sir Thomas a decade later; he was certainly aware of Scott's novel, see, 'Memoir', part 1, p. 353. It is interesting, too, to note that, in a work which appeared just fifteen years after the publication of Woodstock, Lunsford could already be described as 'the celebrated royalist officer', see T. Wright, ed., Political ballads published in England during the Commonwealth (Percy Society, London, 1841), p. 93, footnote (italics added).

108 Most notoriously, Prince Rupert, who eventually took Lunsford's place as 'the quintessential Cavalier', see Stoyle, Black legend, passim; and Withington, 'Peace', p. $15^{1}$.

${ }^{109}$ For a brief account of Sir Thomas's last years, see Morgan, 'Lunsford', pp. 776-7.
} 